\title{
Rituximab: An emerging therapeutic agent for kidney transplantation
}

This article was published in the following Dove Press journal:

Transplant Research and Risk Management

16 October 2009

Number of times this article has been viewed

\author{
Joseph Kahwaji \\ Chris Tong \\ Stanley C Jordan \\ Ashley A Vo
}

Comprehensive Transplant Center, Transplant Immunology Laboratory, HLA Laboratory, Cedars-Sinai Medical Center, Los Angeles, CA, USA
Correspondence: Joseph Kahwaji Comprehensive Transplant Center, Cedars-Sinai Medical Center, $8635 \mathrm{~W}$ 3rd St. Suite 590W, Los Angeles, CA 90048, USA

$\mathrm{Tel}+\mid$ 3I0 $423264 \mid$

Fax +I 3104230234

Email kahwajij@cshs.org
Abstract: Rituximab (anti-CD20, anti-B-cell) is now emerging as an important drug for modification of B-cell and antibody responses in solid-organ transplant recipients. Its uses are varied and range from facilitating desensitization and $\mathrm{ABO}$ blood group-incompatible transplantation to the treatment of antibody-mediated rejection (AMR), post-transplant lymphoproliferative disorder (PTLD), and recurrent glomerular diseases in the renal allograft. Despite these uses, prospective randomized trials are lacking. Only case reports exist in regards to its use in de novo and recurrent diseases in the renal allograft. Recent reports suggests that the addition of rituximab to intravenous immunoglobulin (IVIG) may have significant benefits for desensitization and treatment of AMR and chronic rejection. Current dosing recommendations are based on data from United States Food and Drug Administration-approved indications for treatment of B-cell lymphomas and rheumatoid arthritis. From the initial reported experience in solid organ transplant recipients, the drug is well tolerated and not associated with increased infectious risks. However, close monitoring for viral infections is recommended with rituximab use. The occurrence of progressive multifocal leukoencephalopathy (PML) has been reported with rituximab use. However, this is rare and not reported in the renal transplant population. Here we will review current information regarding the effectiveness of rituximab as an agent for desensitization of highly human leukocyte antigen-sensitized and ABO-incompatible transplant recipients and its use in treatment of AMR. In addition, the post-transplant use of rituximab for treatment of PTLD and for recurrent and de novo glomerulonephritis in the allograft will be discussed. In summary, we will make recommendations based on existing literature and our extensive experience at Cedars-Sinai Medical Center for using rituximab in renal transplantation.

Keywords: kidney transplant, rituximab, desensitization, rejection, review

\section{Introduction}

Renal transplantation has long been recognized as the treatment of choice for end-stage renal disease (ESRD) as it offers improvements in quality and length of life. ${ }^{1-3}$ Currently there are more than 80,000 ESRD patients awaiting transplant in the United States, with more than 30,000 new registrants each year. ${ }^{4}$ However, fewer than 18,000 kidney transplants are performed each year in the United States. ${ }^{4}$ A significant impediment to increasing organ transplantation rates is sensitization to human leukocyte antigen (HLA)-specific allo-antigen and ABO blood group incompatibility. The disparity in waiting time experienced by these patients is directly related to organ allocation policies adopted in the context of ongoing organ shortages which dictates that deceased donor recipients be blood type compatible and have a negative crossmatch with their donors. The scarcity of 
donor organs with these characteristics has contributed to the disenfranchisement of this group of highly HLA-sensitized (HS) ESRD patients and resulted in extensive wait time on dialysis. In addition, if transplanted these patients are at high risk for antibody-mediated rejection (AMR) and allograft loss.

Thus in an effort to optimize organ availability and expand the benefits of kidney transplantation to those patients, several transplant centers have developed protocols to overcome sensitization and blood group incompatibilities. Three desensitization protocols are currently utilized: low-dose intravenous immunoglobulin (IVIG) with plasmapheresis (PP), high-dose IVIG alone, and high-dose IVIG with rituximab. ${ }^{5-7}$ As a direct result of these efforts, it is now possible to perform successful renal transplantation in patients with blood group incompatibilities and a positive crossmatch (CMX).

For decades, the primary focus of transplant immunosuppressive agents was directed at T-cells. The importance of B-cells and antibodies with specificities for HLA in mediating acute rejection and preventing access to transplantation is now widely accepted. ${ }^{8,9}$ However agents specifically directed at modifying B-cell-mediated immune responses have not been available. Over the last several years clinical trials using IVIG have shown the ability to reduce anti-HLA antibodies and improve transplant rates. ${ }^{6,10,11}$ Recently, several investigators have also reported on the beneficial effect of rituximab (anti-B-cell, anti-CD20) in modification of alloimmune responses and treatment of AMR. ${ }^{12-14}$ Here we review current information regarding the effectiveness of rituximab as an agent for desensitization of $\mathrm{HS}$ and ABO-incompatible (ABOi) transplant recipients and its use in the treatment of AMR. In addition, the post-transplant use of rituximab for treatment of PTLD and for recurrent and de novo glomerulonephritis in the allograft will be discussed. In summary, we will make recommendations based on existing literature and our extensive experience at Cedars-Sinai Medical Center for using rituximab in renal transplantation.

\section{Mechanism(s) of action}

Rituximab is a chimeric anti-CD20 (anti-B-cell) monoclonal antibody that is approved for treatment of lymphoma. This antibody efficiently eliminates B-cells as the CD20 antigen is expressed early in B-cell ontogeny, but is absent on mature plasma cells. ${ }^{15,16}$ Rituximab has also been approved for use in rheumatoid arthritis and has demonstrated significant benefit in a number of autoimmune and inflammatory disorders. ${ }^{17,18}$ Of note, is the demonstrated benefit in vasculitic disorders that does not always correlate with reduction in pathogenic antibody. ${ }^{18,19}$ Recent clinical data suggest that the beneficial effects of rituximab may be due to depriving T-cells of antigen presenting cell activity thus altering effector functions and inducing a regulatory profile. ${ }^{20,21}$ This data suggest that the beneficial effects of rituximab on autoimmune disease are more likely related to modification of dysfunctional cellular immunity rather than simply a reduction in antibody.

The variable region of rituximab binds to CD20 and marks the cell for destruction by three different mechanisms: antibody-dependent cell-mediated cytotoxicity (ADCC), complement-dependent cytotoxicity, and cell-mediated apoptosis via CD20 cross-linking. ${ }^{15,22}$ ADCC occurs by binding of the Fc portion of rituximab to Fc $\gamma$ receptors on natural killer (NK) cells, macrophages and monocytes. These cells then act to destroy the B-cell bound by the monoclonal antibody. Complement dependent cytotoxicity is mediated by activation of the complement cascade by the Fc portion of anti-CD20 ultimately resulting in the assembly of the membrane attack complex and cell lysis. Finally, cross-linking of bound CD20 proteins causes an influx of calcium which leads to activation of caspases. This, in turn, causes apoptosis of the cell.

\section{Effect on B-cell populations}

Rituximab causes a profound and sustained depletion in the number of circulating B-cells. It also decreases B-cell populations in the lymph nodes and spleen. A recent study by Genberg and colleagues evaluated the pharmacodynamics after a single dose of rituximab $\left(375 \mathrm{mg} / \mathrm{m}^{2}\right)$ in renal transplant recipients. ${ }^{23}$ Elimination of B-cells was rapid, and occurred over one to three days in the peripheral blood. It was also prolonged. B-cell populations did not begin to reemerge until after one year and remained suppressed for two years. This is longer than what is observed in patients with lymphoma or rheumatoid arthritis. It is notable that B-cell lymphopenia was present at baseline in the renal transplant population. It is possible that the delayed recovery of B-cells was related to the maintenance immunosuppression. Rituximab also leads to a significant reduction of B-cells in lymph nodes, although they were not completely eliminated. It is suggested that the densely populated lymph node is more difficult to penetrate and may require a higher dose of rituximab.

Elimination of some B-cell populations also occurs in the spleen, but not uniformly. This was demonstrated by Ramos and colleagues who determined the effect of rituximab in the spleens of individuals who underwent desensitization. ${ }^{24}$ The investigators quantified B-cells in spleens removed from four groups of patients: those who underwent splenectomy for trauma (control group), those who underwent desensitization 
with plasmapheresis (PP) and low-dose IVIG followed by subsequent splenectomy at the time of transplant (PP/IVIG group), those who underwent desensitization with PP, lowdose IVIG, and rituximab who also had a splenectomy at the time of transplant (PP/IVIG/rituximab group), and those who received rituximab, low-dose IVIG and rabbit antithymocyte globulin (rATG) but not splenectomy (combination group). Splenectomy in the combination group was done in the setting of refractory $\mathrm{AMR}$ and inadequate response to $\mathrm{PP}$ prior to transplant. Naïve B-cells $\left(\mathrm{CD} 20^{+}\right)$were significantly lower in the spleens of those who received rituximab. There was no difference in $\mathrm{CD} 20^{+} \mathrm{B}$-cell depletion between the two rituximabtreated groups. This suggests that the addition of rATG in the combination group did not have an effect on this population of cells. Plasma cells persisted despite treatment with $\mathrm{rATG}$, maintenance immunosuppression, and rituximab.

The effect on memory-B-cells $\left(\mathrm{CD} 27^{+}\right)$is of interest. In the above study by Ramos and colleagues, there was a trend toward a decrease in memory B-cells in the combination group compared to the IVIG/PP/rituximab group. From other studies, B-cell depletion with rituximab is often associated with delayed recovery of memory B-cells and a depletion of pathogenic B-cells. ${ }^{25,26}$ This may prevent development of a memory response to a novel antigen.

\section{Desensitization}

The transplantation of HS individuals poses a great challenge. HS individuals remain on the waiting list significantly longer than their nonsensitized counterparts leading to increased morbidity and mortality. When transplantation occurs, higher rates of rejection and lower rates of graft survival are seen. ${ }^{15}$ Various desensitization protocols have emerged to address this problem. The National Institutes of Health IGO2 trial was a prospective, randomized trial that showed decreases in panel-reactive antibodies (PRA) and improved transplantation rates in HS patients that received four monthly doses of IVIG $(2 \mathrm{~g} / \mathrm{kg}){ }^{6}$ There were more rejections in the group that received IVIG compared to placebo, however, three-year allograft survivals and mean serum creatinines were similar. Unfortunately, this process is lengthy and not uniformly effective. Desensitization protocols employing PP in combination with low-dose IVIG (100 mg/kg) have also had success. ${ }^{27}$ This protocol is usually limited to live donor kidney transplantation because donor-specific antibody (DSA) will likely rebound days after discontinuing the therapy unless transplantation at the nadir of antibody is accomplished.

Rituximab is an attractive adjunct in desensitization protocols based on its success in the treatment of AMR and the synergistic effect with IVIG observed in patients with autoimmune diseases. There are published protocols demonstrating the effectiveness of rituximab for desensitization. ${ }^{28-31}$ Rituximab most commonly is used in combination with PP and/or IVIG. One center reported the efficacy of rituximab used alone for desensitization in five crossmatch (CMX) negative patients. ${ }^{32}$ Rates of acute rejection are high and vary from $20 \%$ to $100 \%$ in these series.

Our group recently reported on our experience using a combination of rituximab and IVIG for desensitization. ${ }^{7}$ In this trial, 20 patients underwent desensitization with IVIG $(2 \mathrm{~g} / \mathrm{kg}$ ) followed by two weekly doses of rituximab (1 g). A final dose of IVIG $(2 \mathrm{~g} / \mathrm{kg})$ was given one week after the last rituximab dose. Patients who subsequently showed a negative or acceptable CMX from a living or deceased donor received allografts. A CMX was deemed acceptable if the T-cell complement-dependent cytotoxicity (CDC) assay was negative at a 1:2 dilution and the T-cell flow cytometric donorspecific CMX had a mean channel shift of less than 250 . Patients received alemtuzumab for induction at the time of transplant and tacrolimus, mycophenolate mofetil, and prednisone for maintenance immunosuppression.

Eighty percent of patients were successfully transplanted with this protocol. Those who were awaiting a deceased donor had an average wait time of 144 months prior to treatment and were transplanted, on average, five months after treatment. There was a 50\% rate of acute rejection, however patient and allograft survival at one year were 100\% and 94\% respectively. This protocol has since been modified to include only one dose of rituximab ( $1 \mathrm{~g}$ ) between the two doses of IVIG (see Figure 1). This was changed due to the long-term B-cell depletion seen with a single dose of rituximab.

In summary, rituximab with PP and/or IVIG facilitates desensitization and allows for transplantation across a positive CMX. Protocols that involve PP are best suited for living donor transplantation. We have found our protocol to be effective for living and deceased donor transplantation while saving time and costs. More recently we have seen low rates of AMR $(23 \%)$ in patients treated with the modified protocol. One-year patient and graft survival rates were $96 \%$ and $94 \%$, respectively. ${ }^{33}$

\section{Concerns regarding rituximab interference with crossmatch results}

The use of rituximab interferes with the B-cell CDC and B flow cytometric CMX. Rituximab activates complement, which results in a false positive B-cell $\mathrm{CMX} .{ }^{34}$ One can 


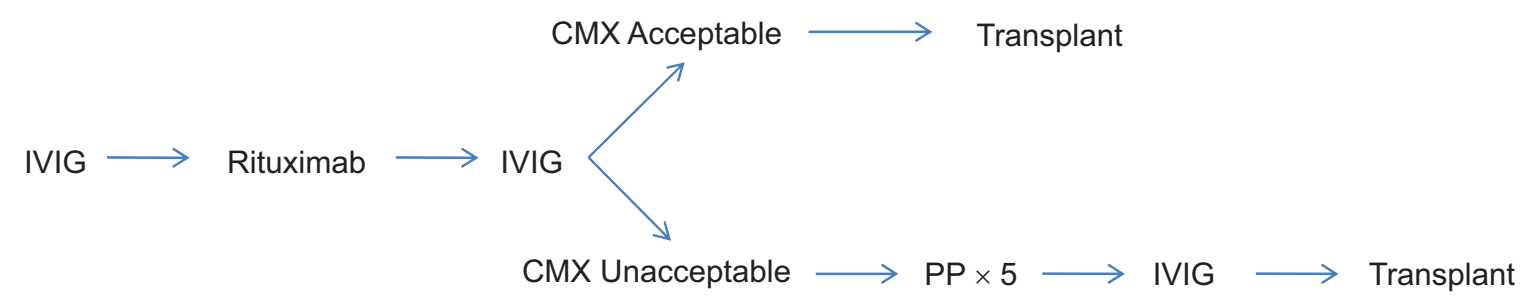

\section{CSMC HLA desensitization protocol}

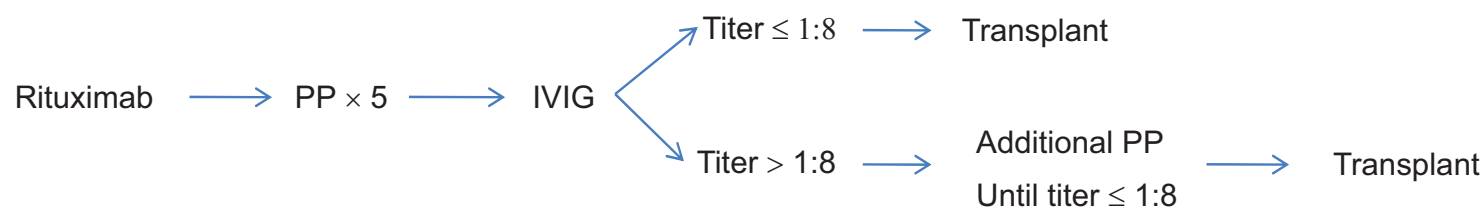

\section{CSMC ABOi preconditioning protocol}

Figure I Cedars-Sinai Medical Center (CSMC) protocols.

Abbreviations: $A B O i, A B O$ incompatible; CMX, crossmatch; IVIg, intravenous immunoglobulins; HLA, human leukocyte antigen; MMF, mycophenolate mofetil; $\mathrm{PP}$, plasmapheresis.

disregard the B-cell CMX in rituximab-treated individuals; however this may lead to severe early AMR in HS patients with HLA class II antibodies. Pronase is a proteolytic enzyme that removes the Fc receptors from the surface of B- and T-cells, and improves the sensitivity and specificity of the CMX. CD20 is removed by pronase treatment as well. Pronase treatment was shown to reduce or eliminate the effect of rituximab on the B-cell flow cytometric CMX.${ }^{34}$ Our experience with this technique is evolving and, as yet, is not always reproducible.

\section{ABO-incompatible transplantation}

The scarcity of organ donors, both living and deceased, contributes to the ever growing transplant wait list. Kidney transplantation across blood group barriers provides a means to expand the donor pool. Early experience involved removing anti-A/B antibodies by PP followed by three-drug immunosuppression and splenectomy to prevent severe AMR.$^{35}$ ABOi transplantation has since been used, especially in Japan, as a way to expand the donor pool. Sawada and colleagues were the first to report on the successful use of rituximab to lower anti-blood group antibodies in preparation for ABOi transplantation. ${ }^{36}$

Rituximab has now largely replaced splenectomy in ABOi preconditioning protocols. In 2003, ABOi transplants were successfully performed in four patients without splenectomy under a preconditioning regimen consisting of a single dose of rituximab, antigen-specific immunadsorption, and three-drug immunosuppression. ${ }^{37}$ Sonnenday and colleagues subsequently reported successful ABOi transplantation in six patients that received multiple sessions of PP followed by CMV immune globulin and a single dose of rituximab given one to two days prior to transplant. ${ }^{5}$ Tacrolimus and mycophenolate mofetil were started at the initial PP and the patients received induction with steroids and daclizumab. Excellent results were achieved after twelve months of follow-up. Patient and allograft survival were $100 \%$ with no episodes of AMR. There was one episode of cell-mediated rejection (CMR) discovered by protocol biopsy at three months post-transplant. Shortterm data from multiple medical centers show similar excellent results with good allograft survival and low rates of rejection utilizing different protocols that include rituximab. ${ }^{38-40}$

There are now long-term data supporting the efficacy of rituximab in ABOi preconditioning protocols. Genberg and colleagues reported their three-year experience with ABOi transplantation using rituximab instead of splenectomy. ${ }^{41}$ The study was a comparative, retrospective design that compared ABOi to ABO-compatible recipients who were transplanted during the same time period. There were 15 ABOi and $30 \mathrm{ABO}$-compatible adult recipients. There was no difference in patient survival, allograft survival, or rates of rejection between the two groups. There was also no 
difference in serum creatinine, glomerular filtration rate, and proteinuria between the two groups at three years. Recently, Montgomery and colleagues reported on the Johns Hopkins University experience with ABOi transplantation. ${ }^{42}$ The one-, three-, and five-year graft survival rates were 98.3\%, 92.9\%, and $88.7 \%$, respectively. Only $15 \%$ of the patients had AMR episodes. The authors used three different protocols. The final did not include the use of B-cell depletion. However other investigators feel this is an important part of ABOi transplantation.

Our group has adopted a protocol that employs administration of rituximab ( $1 \mathrm{~g})$ one week prior to initiating five sessions of PP followed by IVIG (2 g/ $/ \mathrm{kg}$ ) (see Figure 2). Our goal is to reduce the anti-blood group titer to $\leq 1: 8$. This regimen has yielded excellent results with 18 patients transplanted to date, $66 \%$ of whom have had one-year follow-up. There is $100 \%$ patient survival and $94 \%$ graft survival after one year. ${ }^{43}$

\section{Effect of anti-CD20 therapy in a mouse model of sensitization}

Recently our group reported on development of a mouse model of HLA sensitization that was used to study the effectiveness of anti-CD20 treatment on B-cell depletion and anti-HLA antibody responses. ${ }^{44}$ This model utilized skin grafts from C57BLTr/HLA-A 2.1 mice to
C57BL/6mice. Immunization with the skin grafts from the HLA A2.1 transgenic animals resulted in a robust production of anti-HLA immunoglobulin M (IgM) and IgG antibodies with specificities to HLA A2.1 and multiple HLA class 1 targets, including A1, A3, A25, A26, A29, and A30. These antibodies also were cytotoxic to HLA A2-expressing target cells. Administration of two doses of a novel mouse anti-mouse rituximab (development in $\mathrm{CD} 20^{-/-}$mice) significantly suppressed levels of anti-HLA IgG2a antibodies, prolonged survival of secondary skin grafts, and reduced IgG deposits and C4d staining of these grafts. Administration of this antibody was also associated with a significant depletion of $\mathrm{B} 220^{+} / \mathrm{CD}^{-} \mathrm{B}-\mathrm{cells}$. Overall this experimental data suggests that rituximab may have an important role in desensitization therapies and in the treatment of AMR.

\section{Treatment of antibody-mediated rejection}

AMR remains a significant problem and is a detriment to long-term renal allograft survival. The rate of AMR in patients undergoing desensitization is currently $19 \%{ }^{45}$ However, the rates of AMR are much higher in PP-based protocols. ${ }^{46,47}$ Rituximab was initially used for the treatment of refractory rejection based on the recognition of intrarenal B-cell infiltrates in both CMR and AMR. ${ }^{48}$ The presence of

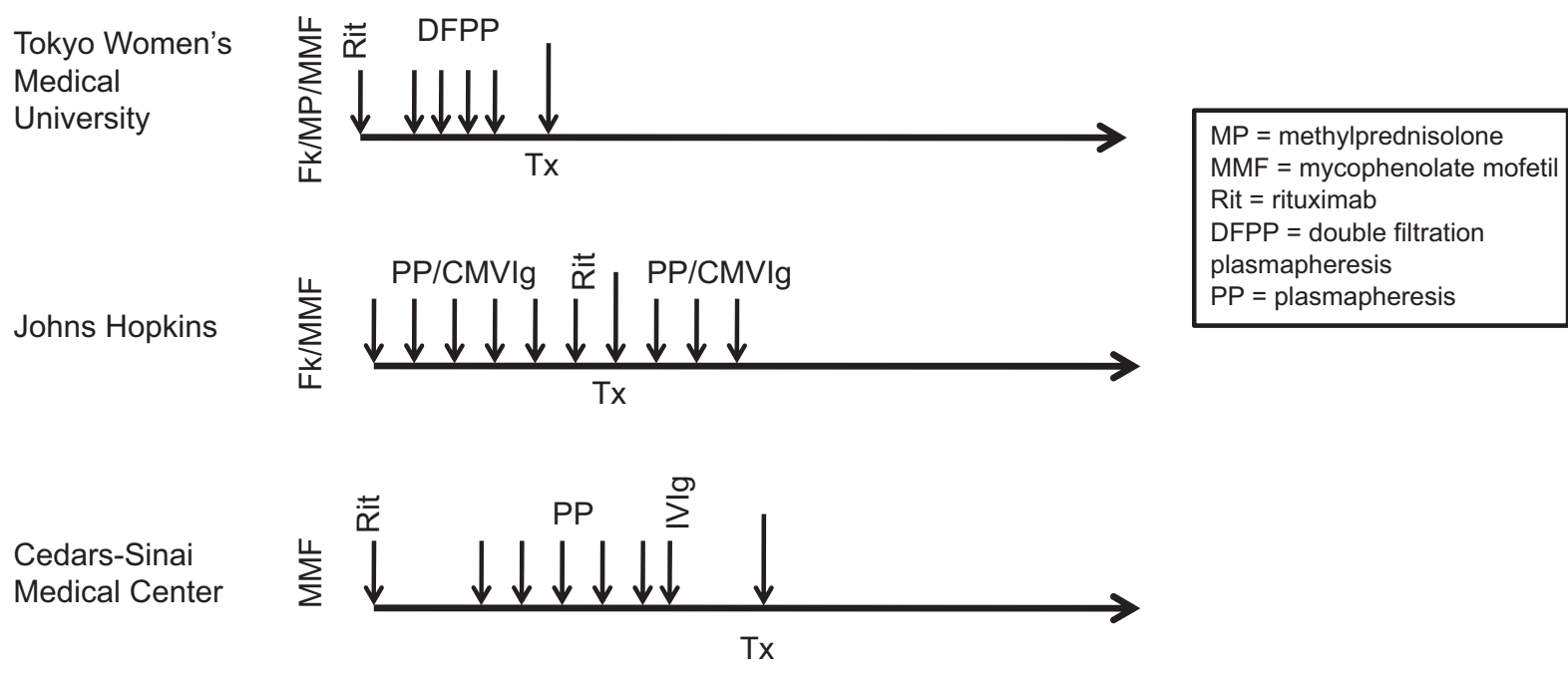

Pre-conditioning protocols for $\mathrm{ABOi}$ transplantation

Figure 2 Preconditioning protocols for $A B O i$ transplantation.

Abbreviations: ABOi, ABO incompatible; DFPP, double filtration plasmapheresis; IVlg, intravenous immunoglobulins; MMF, mycophenolate mofetil; MP, methylprednisolone; RIT, rituximab; PP, plasmapheresis. 
B-cell infiltrates in acute CMR is a risk factor for steroid resistance and is associated with a worse prognosis. ${ }^{48,49}$ It is unclear if the B-cells present within the allograft function as plasma cell precursors, antigen presenting cells, and/or provide co-stimulatory signals to T-cells. B-cells also produce inflammatory cytokines that may directly injure the allograft.

The effect of rituximab on B-cell infiltration was reported in two studies. Zarkhin and colleagues prospectively studied pediatric renal transplant recipients who had biopsy proven CMR with B-cell infiltrates. ${ }^{12}$ Patients were randomized to receive four weekly doses of rituximab $\left(375 \mathrm{mg} / \mathrm{m}^{2}\right)$ plus standard treatment versus standard treatment alone. The B-cell infiltrate was abolished in all cases after rituximab treatment with improvement in renal function. Steinmetz and colleagues identified nine patients with vascular allograft rejection and B-cell clusters present in biopsy specimens. ${ }^{50}$ Patients who received one dose of rituximab $\left(375 \mathrm{mg} / \mathrm{m}^{2}\right)$ in addition to conventional treatment had complete resolution of the B-cell infiltrate. Both studies were small and no differences were seen in clinical outcomes between the groups. It is notable that complete resolution of the B-cell infiltrate was seen whether patients received one dose of rituximab or four doses.

Many recent reports support the clinical efficacy of rituximab for the treatment of AMR (Table 1). Becker and colleagues initially reported the benefit of rituximab in the treatment of refractory rejection. ${ }^{51}$ The investigators evaluated 27 patients who received rituximab for refractory AMR diagnosed by the presence of thrombotic microangiopathy (TMA) or endothelitis in renal allograft biopsies. Patients received treatment with steroids, $\mathrm{PP}$, and/or antithymocyte globulin (ATG) without improvement in creatinine prior to receiving a single dose of rituximab $\left(375 \mathrm{mg} / \mathrm{m}^{2}\right)$. There were three graft losses. The 24 successfully treated patients had good allograft function at the time of discharge. Other

Table I Overview of rituximab for AMR

\begin{tabular}{|c|c|c|c|c|}
\hline Author & Study type & Subjects & Protocol & Results \\
\hline $\begin{array}{l}\text { Becker et al } \\
2004\end{array}$ & Case series & $\begin{array}{l}\mathrm{N}=27 \\
\text { Adults Rejection (TMA or } \\
\text { endothelitis without cellular } \\
\text { infiltrate) refractory to } \\
\text { steroids or ATG/PP }\end{array}$ & Single dose of RIT $\left(375 \mathrm{mg} / \mathrm{m}^{2}\right)$ & $\begin{array}{l}89 \% \text { Graft survival } \\
\text { Average } \mathrm{Cr} 0.95 \text { at discharge }\end{array}$ \\
\hline $\begin{array}{l}\text { Wade et al } \\
2006\end{array}$ & Case series & $\begin{array}{l}\mathrm{N}=3 \\
\text { Adults AMR }\end{array}$ & $\begin{array}{l}\text { RIT given with various } \\
\text { combinations of PP, steroid, } \\
\text { OKT3, and IVIG }\end{array}$ & I of 3 responded to treatment \\
\hline $\begin{array}{l}\text { Faguer et al } \\
2007\end{array}$ & Case series & $\begin{array}{l}\mathrm{N}=8 \\
\text { Adults AMR }\end{array}$ & $\begin{array}{l}\text { RIT }\left(375 \mathrm{mg} / \mathrm{m}^{2} \text { weekly } \times 4\right) \\
\text { with steroids and PP + various } \\
\text { additional treatments }\end{array}$ & $\begin{array}{l}10 \mathrm{~m} \text { average follow-up } \\
\text { Graft survival } 75 \% \\
\text { Cr improved }(P=0.04)\end{array}$ \\
\hline $\begin{array}{l}\text { Zarkin et al } \\
2008\end{array}$ & $\begin{array}{l}\text { Randomized, } \\
\text { prospective trial }\end{array}$ & $\begin{array}{l}\mathrm{N}=20 \\
\text { Pediatrics } \mathrm{CD} 20^{+} \text {rejection }\end{array}$ & $\begin{array}{l}\text { Patients randomized to standard } \\
\text { care or standard care plus RIT } \\
375 \mathrm{mg} / \mathrm{m}^{2} \times 4 \text { doses }\end{array}$ & $\begin{array}{l}\text { I } 2 \text { m Follow-up } \\
\text { Improved } \mathrm{Cr} \text { in RIT group } \\
(P=0.026)\end{array}$ \\
\hline $\begin{array}{l}\text { Mulley et al } \\
2009\end{array}$ & Pilot study & $\begin{array}{l}\mathrm{N}=7 \\
\text { Adults AMR }\end{array}$ & $\begin{array}{l}\text { Single-dose rituximab }(500 \mathrm{mg}) \\
\text { for AMR refractory to PP/low } \\
\text { dose IVIG }\end{array}$ & $\begin{array}{l}20 \mathrm{~m} \text { average follow-up } \\
\mathrm{Cr} \text { improved }(P=0.49) \\
100 \% \text { allograft survival }\end{array}$ \\
\hline $\begin{array}{l}\text { Kasposztas et al } \\
2009\end{array}$ & $\begin{array}{l}\text { Retrospective } \\
\text { case-control }\end{array}$ & $\begin{array}{l}\mathrm{N}=54 \\
\text { Adults AMR }\end{array}$ & $\begin{array}{l}\text { PP plus RIT } \pm \text { IVIG vs PP } \\
\text { alone } \pm \text { IVIG }\end{array}$ & $\begin{array}{l}24 \text { m follow-up } \\
\text { Graft survival } 90 \% \text { (ritux) vs } \\
60 \% \text { (control) }(P=0.005) \\
\text { Mean GFR no change } \\
(P=0.42)\end{array}$ \\
\hline $\begin{array}{l}\text { Tanriover et al } \\
2008\end{array}$ & Pilot study & $\begin{array}{l}\mathrm{N}=7 \\
\text { Adults AMR }\end{array}$ & $\begin{array}{l}\text { RIT }\left(375 \mathrm{mg} / \mathrm{m}^{2}\right) \text { with } \\
\operatorname{IVIG}(2 \mathrm{~g} / \mathrm{kg})\end{array}$ & $\begin{array}{l}24 \text { m follow-up } 86 \% \text { one-year } \\
\text { allograft survival } \\
58 \% \text { two-year allograft survival }\end{array}$ \\
\hline $\begin{array}{l}\text { Billing et al } \\
2008\end{array}$ & Pilot study & $\begin{array}{l}\mathrm{N}=6 \\
\text { Pediatric (one adult) } \\
\text { Chronic AMR }\end{array}$ & $\begin{array}{l}\text { IVIG }(\mathrm{I} \mathrm{g} / \mathrm{Kg}) \text { weekly } \times 4 \text { doses } \\
\text { followed by RIT } 375 \mathrm{mg} / \mathrm{m}^{2} \times \\
\text { I dose }\end{array}$ & $\begin{array}{l}\text { I } 2 \text { m follow-up } \\
\text { GFR stabilized in } 4 / 6 \text { patients }\end{array}$ \\
\hline
\end{tabular}

Abbreviations: AMR, antibody-mediated rejection; ATG, antithymocyte globulin; $\mathrm{Cr}$, creatinine; IVlg, intravenous immunoglobulins; m, month; PP, plasmapheresis; RIT, rituximab; TMA, thrombotic microangiopathy. 
recent reports also document a beneficial effect of rituximab on refractory AMR. ${ }^{13,52,53}$

Kaposztas and colleagues reported two-year outcomes in their recent retrospective study looking at 54 patients treated for AMR. ${ }^{13}$ Group A had 26 patients that underwent treatment with PP and rituximab and Group B had 28 patients who received PP without rituximab. Patients that had low serum IgG levels also received IVIG. Two-year graft survival was significantly better in the group that received rituximab ( $90 \%$ versus $60 \%$ ) with the difference attributed to rituximab. A trend toward improved graft survival was also seen in those that received IVIG $(P=0.050)$. This study has one of the largest cohorts reported to date and supports the use of rituximab for the treatment of AMR with good short-term allograft survival. However, the study was retrospective with many patient variables that were not consistent between the groups.

Approaches to the treatment of AMR include high-dose IVIG, PP combined with lower dose IVIG, or rituximab. ${ }^{54}$ The effectiveness of rituximab is reported in combination with IVIG, PP, and/or steroids. ${ }^{13,55-57}$ The ameliorative effects of rituximab on AMR are likely multifactorial. In addition to B-cell depletion and reduction in DSA, disruption of T-cell co-stimulator and antigen-presenting cell activities mediated by B-cells are likely altered and result in diminished T-cell effector functions. ${ }^{54}$ Optimal treatment of AMR probably requires a combination of rituximab with $\mathrm{PP}$ and low-dose IVIG or with high-dose IVIG $(1-2 \mathrm{gm} / \mathrm{kg}){ }^{54}$ This is related to the inability of rituximab to deplete CD20 negative plasma cells that continue to produce DSA and mediate graft injury.

Our center has extensive experience with HS patients who received kidney transplants after desensitization with IVIG and rituximab. ${ }^{7}$ Recently, we evaluated 123 HS patients transplanted after desensitization (7/06-2/09). Twenty-two patients developed AMR post-transplant, usually within the first month. All were treated with a combination of steroids (10 $\mathrm{mg} / \mathrm{kg}$ daily $\times 3$ ), IVIG $2 \mathrm{gm} / \mathrm{kg}$ (maximum dose $140 \mathrm{~g} \times 1$ ), and rituximab $\left(375 \mathrm{mg} / \mathrm{m}^{2} \times 1\right)$. Some patients also received PP and two underwent splenectomy. Six of twenty-two patients (27\%) lost their allograft to severe AMR, usually within one month. Thus, a $73 \%$ survival rate for severe AMR was seen in this high-risk group. ${ }^{33}$

Chronic antibody-mediated rejection (CAMR) is defined by criteria set forward in Banff in 2005. ${ }^{58}$ CAMR has a poor prognosis with no currently well defined treatment protocol. ${ }^{59}$ Billing and colleagues conducted a pilot study to investigate the use of IVIG with rituximab in six patients (aged 10-26 years) that had evidence of CAMR. ${ }^{60}$ The patients received four weekly doses of IVIG $(1 \mathrm{~g} / \mathrm{kg})$ followed by one dose of rituximab $\left(375 \mathrm{mg} / \mathrm{m}^{2}\right)$. All patients showed greater than $40 \%$ positive $\mathrm{C} 4 \mathrm{~d}$ staining of peritubular capillaries. All biopsies had varying degrees of CD20 $0^{+}$infiltrates. Allograft function stabilized or improved in four patients after one year of observation. There was one graft loss at 18 months and one patient did not respond. Five out of six patients had complete depletion of B-cells in the peripheral blood. The two patients that did not respond had the highest degree of transplant glomerulopathy.

In summary, reports have demonstrated the efficacy of rituximab for treating refractory rejection, rejection that contains B-cell infiltrates, AMR, and CAMR. The available evidence suggests an improvement in creatinine and allograft survival in the short- and medium-term. The efficacy of rituximab is mostly seen when it is used in combination with other therapies for rejection, such as steroids, IVIG, or PP. Prospective randomized trials are now needed to validate the existing data and to clarify the dosing regimen.

\section{Post-transplant lymphoproliferative disorder (PTLD)}

The incidence of PTLD varies from $1.3 \%$ in kidney transplant recipients to $8.2 \%$ in lung transplant recipients. ${ }^{61}$ The incidence is higher in the pediatric population. Risk factors for PTLD include Epstein-Barr virus (EBV) status, type of organ transplanted and intensity of immunosuppression. EBV positivity has ranged from $29 \%$ to $100 \%$ in patients who developed PTLD. ${ }^{62}$ The majority of these tumors are CD20 ${ }^{+}$B-cell clones; mostly diffuse large cell lymphomas. Poor prognostic indicators include EBV-naïve recipients, advanced age, elevated lactate dehydrogenase (LDH), and an increased number of involved sites. Initial management has been reduction in immunosuppression, but response to this is reported to be variable and low. ${ }^{63}$ Additional treatment strategies include antiviral therapy, interferon alpha, EBV-specific T-cell infusion, chemotherapy, and rituximab. ${ }^{62-65}$

The use of rituximab to treat PTLD, including central nervous system involvement, was described in various reports and retrospective studies with response rates ranging from $44 \%$ to $65 \%$. $^{62,66}$ There have since been three prospective trials evaluating the safety and efficacy of rituximab used as a single agent to treat PTLD. ${ }^{67-69}$ Patients were initially treated with reduced immunosuppression. This was followed by four weekly doses of rituximab $\left(375 \mathrm{mg} / \mathrm{m}^{2}\right)$ if there was no response to initial reduction in immunosuppression. Rituximab infusion was well tolerated and only two of 52 adverse events were related to rituximab in the largest study. ${ }^{67}$ EBV positivity and a normal LDH level predicted the response 
to rituximab therapy. The patients that did not respond to rituximab in one study $(n=7)$ had late onset, EBV-negative PTLD. ${ }^{68}$ Based on these studies, rituximab is useful to treat low risk, EBV-positive tumors. However chemotherapy, with or without rituximab, should be considered in patients with EBV-negative tumors, elevated LDH or late onset PTLD.

Multiple studies have also evaluated the efficacy of rituximab treatment in combination with chemotherapy. ${ }^{70-72}$ Orjuela and colleagues conducted a pilot study in a small group of pediatric solid organ transplant recipients. ${ }^{71}$ This group of patients usually has more aggressive PTLD. They were treated concurrently with rituximab, cyclophosphamide, and prednisone. Five out of the six patients achieved complete remission during the follow-up period, eight to 29 months. A large, retrospective study evaluated solid organ transplant recipients that received rituximab alone or chemotherapy with or without rituximab after failing reduction of immunosuppression for PTLD. ${ }^{72}$ The response rate for single-agent rituximab was $68 \%$. There was a $74 \%$ response rate in those that received chemotherapy with or without rituximab. However, significant toxicity was associated with chemotherapy. The authors concluded that it would be reasonable to consider rituximab for treatment of PTLD if reduction in immunosuppression fails. Chemotherapy should be reserved for those individuals who fail rituximab treatment alone, those who need a rapid response, or those with EBV-negative disease.

Surveillance for EBV viremia is one measure that can be taken to prevent development of PTLD. This has been studied in patients that have undergone hematopoietic stem cell transplantation. Meerbach and colleagues screened 123 patients weekly after transplantation for EBV reactivation. ${ }^{73}$ Twenty-five percent of patients developed EBV reactivation, 19.5\% subclinical EBV viremia, and three patients developed PTLD. EBV levels normalized after reduction in immunosuppression. Four patients received pre-emptive therapy with cidofovir and rituximab because of a high viral load. The high EBV viral load was reduced in all patients with this treatment. Pre-emptive therapy was also explored in 27 pediatric patients who underwent stem cell transplantation. ${ }^{74}$ EBV viral DNA was eliminated in eight patients who received rituximab; however four of these patients had a secondary increase in EBV viral load coincident with the emergence of $\mathrm{CD} 20^{-} \mathrm{B}$-cells.

We believe monitoring for EBV post-kidney transplant is a reasonable approach to identify and prevent PTLD in renal transplant recipients. Reduction in immunosuppression may be of more benefit if it is initiated earlier, before PTLD occurs, as suggested above. Single-agent rituximab therapy should be given in those with an elevated EBV viral load despite reduction in immunosuppression. Rituximab is also helpful for treating PTLD with low-risk features and EBV positivity. Other therapies such as interferon alpha and chemotherapy should be used in cases of PTLD that are refractory to rituximab or have poor prognostic risk factors such as EBV negativity or elevated LDH level.

\section{Recurrent and de novo diseases in the renal allograft}

Rituximab has been used for the treatment of various immune mediated glomerular diseases in the native kidneys. Most of the experience in treating recurrent disease in renal allografts is limited to case reports. In 2006, Becker and colleagues cited only three case reports of rituximab being used for recurrent disease in the renal allograft. ${ }^{65}$ Since then, there have been numerous case reports describing the effectiveness of rituximab for various recurrent or de novo glomerular diseases including focal segmental glomerulosclerosis (FSGS), membranous nephropathy (MN), antineutrophil cytoplasmic antibodies (ANCA)-associated vasculitis, mixed cryoglobulinemia (MC), and TMA. We are unaware of any case reports discussing the use of rituximab for membranoproliferative glomerulonephrotis (MPGN) type 1 or 2 despite the high recurrence rate of these diseases. Controlled trials examining the benefit of rituximab in these diseases are difficult to conduct considering the rarity of recurrent glomerular diseases in renal allografts. However, the mounting case reports provide a framework for treatment of recurrent and de novo diseases in the renal allograft that have traditionally had few therapeutic options.

Idiopathic FSGS recurs in up to $30 \%$ of initial renal transplants and as high as $80 \%$ in second transplants. ${ }^{75}$ It is manifested by proteinuria, often nephrotic range, with or without allograft dysfunction. Allograft survival is poor without any treatment. It is hypothesized that the pathogenesis involves a circulating permeability factor. Treatment has consisted of PP, cyclophosphamide, high-dose cyclosporine, and renin-angiotensin system blockade. Multiple case reports have documented improvement in proteinuria after rituximab treatment in combination with PP or immunoadsorption. ${ }^{76-81}$ Remission was sustained from six months to over two years in some cases.

However, failure of rituximab to improve nephrotic syndrome in four consecutive cases of recurrent FSGS was reported by Yabu and colleagues. ${ }^{75}$ The patients studied in this report had recurrent FSGS that either did not respond or 
relapsed after PP therapy. They were subsequently treated with multiple doses of rituximab. Rituximab alone was unable to improve proteinuria in this case series. It is unclear what factors are responsible for individual patient responses. There may be differences in the underlying pathological processes among individuals causing FSGS. It appears that the patients who responded to rituximab therapy were treated early in the post-transplant period.

$\mathrm{MN}$ has a much lower rate of recurrence in renal allografts compared to FSGS. However, $25 \%$ of patients with recurrent $\mathrm{MN}$ lose their allografts to the disease. Recurrent disease usually occurs within the first year post-transplant. In contrast, de novo $\mathrm{MN}$ in the renal transplant, the most common de novo glomerulopathy in renal transplant recipients, occurs years after transplant. Rituximab was reported to improve proteinuria in patients with native kidney $\mathrm{MN} .{ }^{82}$ It is possible that B-cell depletion decreases antibody deposition onto the podocyte membrane and eliminates damage. Based on this, there are case reports of rituximab treatment for recurrent $\mathrm{MN}$ in kidney transplant recipients. ${ }^{83-86}$ In these cases, all patients had biopsy-proven recurrent $\mathrm{MN}$ diagnosed within one year of transplant. Rituximab was given initially in four weekly doses in all cases with additional doses every four months up to one year in the other two cases. Improvement in proteinuria and nephrotic syndrome was seen in all cases for the duration of follow-up, 24 to 42 months.

One case report demonstrated improvement of nephrotic syndrome in a patient with de novo $\mathrm{MN}$ diagnosed 30 months after transplantation. ${ }^{86}$ De novo $\mathrm{MN}$ is often associated with CAMR, and indeed, this patient had a PRA of $80 \%$ prior to transplant. His biopsy showed a mild plasma cell infiltrate. He was treated with pulse steroids, renin-angiotensin system blockade and one dose of rituximab. His nephrotic syndrome resolved and renal function was stable with minimal proteinuria 18 months after treatment.

The evidence for rituximab therapy in the treatment of ANCA-associated vasculitis is limited. ANCA-associated vasculitis is a group of diseases characterized by necrotizing glomerulonephritis with a paucity of immune complex deposition on renal biopsy. Renal survival was only $72 \%$ in one series in patients with Wegener's granulomatosis (WG) or microscopic polyangiitis (MPA). ${ }^{87}$ Renal transplant is successful in patients with renal vasculitis with an overall recurrence rate of $8 \%$ to $17 \%{ }^{88,89}$ Rituximab is reported to induce remission in cases of ANCA-associated vasculitis refractory to treatment with cyclophosphamide. ${ }^{90,91} \mathrm{~B}$-cells are precursors to ANCA-producing plasma cells and their depletion may induce remission.
There are a few case reports of recurrent ANCA vasculitis in renal transplant recipients that resolved after treatment with rituximab. One report discussed nonrenal recurrence of WG in a renal transplant recipient successfully treated with rituximab. ${ }^{92}$ Geetha and colleagues reported two cases of recurrent ANCA vasculitis with renal manifestations. ${ }^{88}$ Recurrent disease was diagnosed by biopsy in both cases. Microscopic hematuria and dysmorphic red blood cells were seen in one case, and microscopic hematuria with proteinuria and increased creatinine was noted in the other. Rituximab was given in four weekly doses to each patient after they failed to respond to steroid therapy. Standard therapy with cyclophosphamide was not used in the first case due to concerns for infertility and avoided in the second case because of a history of intolerance. Remission was achieved in both patients with resolution of hematuria and improvement in creatinine.

Rituximab has also been used to treat $\mathrm{MC}$ in renal transplant recipients. ${ }^{93-96}$ The use of rituximab for the treatment of $\mathrm{MC}$ was based on reports from nonimmunocompromised patients. ${ }^{97,98}$ Its use was first reported in three renal transplant patients that acquired $\mathrm{MC}$ de novo after transplantation. ${ }^{93}$ One patient had chronic hepatitis $\mathrm{C}$ virus $(\mathrm{HCV})$. Rituximab resolved proteinuria and cryoglobulins in all three patients, but two patients suffered serious infectious complications. The same authors reported improvement in nephrotic syndrome, renal function, and cryoglobulins in a subsequent case series. ${ }^{94}$ This series consisted of seven renal transplant recipients, five of whom had chronic $\mathrm{HCV}$, who received multiple doses of rituximab.

TMA occurs in the renal allograft as de novo or recurrent disease. Nondiarrhea-associated hemolytic uremic syndrome (HUS), demonstrated by TMA in the renal allograft, can recur in up to $33 \%$ to $56 \%$ of adults and $21 \%$ to $28 \%$ of children depending on the mutation responsible for the disease. ${ }^{99}$ De novo TMA is rare, but the incidence can be as high as $20 \%$ in some medical centers. ${ }^{100}$ Risk factors for de novo TMA in the renal allograft include treatment with calcineurin inhibitors or mTOR inhibitors, AMR, viral infection, or ischemia reperfusion injury. There are few case reports discussing the efficacy of rituximab for treating TMA. A single case report describes a case of recurrent HUS that was refractory to over 40 PP treatments. ${ }^{101}$ Multiple doses of rituximab were subsequently administered with stabilization of the disease. Some cases of HUS are caused by anti-factor $\mathrm{H}$ autoantibodies which provide a rationale for rituximab treatment.

Only anecdotal evidence exists describing the success of rituximab for de novo TMA. A primary cause of TMA 
in native kidneys is the presence of autoantibodies to ADAMTS-13 (a disintegrin-like and metalloproteinase domain with thrombospondin repeats). ${ }^{102}$ Patients with genetic deficiency of or autoantibodies to this enzyme cannot degrade ultra heavyweight von Willebrand Factor (UHWVWF) and are predisposed to TMA after vascular injury. There are case reports describing the efficacy of rituximab for treatment of TMA. This efficacy is likely due to reduction or elimination of circulating auto-antibodies to ADAMTS-13. ${ }^{103-105}$

Rituximab has shown efficacy in treating recurrent and de novo glomerular diseases in renal allografts. However evidence is limited to case reports. Prospective, randomized trials will likely not take place due to the rarity of these diseases. The decision to use rituximab for glomerular diseases in the renal allograft should be based on the safety and efficacy of the current standard therapies including a discussion of the risks and benefits of alternative therapies with the patient.

\section{Infectious complications}

The risk for infectious complications following rituximab administration is concerning. A trend toward an increased rate of infections was reported in a small group of patients $(n=21)$ that received rituximab for ABOi transplantation or a positive CMX. ${ }^{106}$ There was no difference in patient or graft survival. Patients treated with rituximab in this series also received ATG. Types of infections included blood stream infection, pneumonia, esophagitis, peritonitis, colitis, and skin and soft tissue infection. Cryptococcal infection and disseminated herpes simplex virus 2 were also reported in three patients that received rituximab for the treatment of $\mathrm{MC} .{ }^{93}$ Furthermore, three bacterial infections and two fungal infections were reported in eight patients that received rituximab for the treatment of AMR. ${ }^{14}$

Several studies have reported viral infections following rituximab administration ${ }^{39,40,107,108}$ (Table 2). In a literature review conducted by Aksoy and colleagues, there were 64 serious viral infections identified in a group of patients, not primarily transplant recipients, treated with rituximab for lymphoma. ${ }^{108}$ They found the most common viral infections to be hepatitis B virus (HBV), cytomegalovirus (CMV), and varicella zoster virus. A high rate of CMV viremia was also reported in a group of patients that received rituximab for ABOi preconditioning. ${ }^{39,40}$ This group of patients did not receive CMV prophylaxis, but underwent surveillance for CMV viremia. All were successfully treated with injectable ganciclovir administered at the first sign of viremia.
Table 2 Viral infections associated with rituximab
Cytomegalovirus
Polyomavirus BK
Polyomavirus JC
Herpes simplex virus
Varicella zoster
Parvovirus B 19

The development of progressive multifocal leukoenchephalopathy (PML) in patients treated with rituximab is of considerable concern. Safety alerts were issued by the US Food and Drug Administration, the European Medicines Agency, and the World Health Organization in 2006 and 2007, which described two cases of PML in patients with systemic lupus erythematosis treated with rituximab and other immunosuppressive agents. PML is a progressive neurological disorder first described in patients with non-Hodgkin's lymphoma and chronic lymphocytic leukemia. ${ }^{109}$ It was an acquired immune deficiency syndrome (AIDS)-defining illness prior to the development of highly active antiretroviral therapy. It is caused by the reactivation of latent $\mathrm{JC}$ polyoma virus $(\mathrm{JCV})$ as a result of defects in cellular immunity. A recent literature review identified 57 cases of PML in non-HIV infected individuals treated with rituximab. ${ }^{110}$ There were 52 cases in patients with B-cell lymphoproliferative disorders and five cases in patients treated for autoimmune diseases. There were no cases reported in renal transplant recipients. A case fatality rate of $90 \%$ was reported, with those diagnosed within three months of rituximab infusion having a 100\% mortality rate.

Although PML is rare after rituximab infusion, the high fatality associated with it has lead to consideration for JCV screening after treatment in patients with solid organ transplants. Kamar and colleagues screened 73 solid organ transplant recipients who received rituximab, 37 of whom received a kidney transplant, for JCV reactivation. ${ }^{111}$ They assessed JCV DNA in whole blood by qualitative real-time polymerase chain reaction (PCR). Monitoring was done every three to four months after rituximab administration with an average follow-up of 13 months. Polyoma BK virus (BKV) was also assessed. JCV was detected in $5.5 \%$ of patients; one time in three patients and five times in a fourth patient. They were all in renal transplant patients who had also received T-cell-depleting agents. No cases of PML developed and all patients responded to a reduction in immunosuppression. BK virus-associated nephropathy, diagnosed by biopsy after a positive PCR, occurred in all four patients with JCV 
reactivation. The authors concluded that monitoring for JCV is useful for identifying patients who are over immunosuppressed.

Reactivation of parvovirus B19 has also been documented after rituximab administration in two nontransplant patients. ${ }^{12,113}$ One patient developed pure red cell aplasia after being treated for lymphoma and another pancytopenia after treatment for refractory immune thrombocytopenic purpura. Both patients recovered. Although hematologic disturbances may be a side effect of rituximab, one must be aware that they are also a sign of reactivated viral infections such CMV or parvovirus B19.

Despite the above findings, there are many reports that have demonstrated the safety of rituximab administration with infection rates similar to those seen in renal transplant recipients who did not receive rituximab. ${ }^{7,12,32,41,114} \mathrm{We}$ reported a series of $20 \mathrm{HS}$ patients who received IVIG and rituximab for desensitization followed by induction with the lymphocyte-depleting antibody alemtuzumab. ${ }^{114}$ There were no viral infections seen and seven bacterial infections, all related to asymptomatic urinary tract infection. All patients received CMV prophylaxis and prophylaxis for Pneumocystis carinii (P. jirovecii) pneumonia. PCR assays for CMV, EBV, parvovirus $\mathrm{B}-19$, and polyomavirus $\mathrm{BK}$ were performed on whole blood specimens monthly for six months. We concluded that there is no increased risk of infectious complications with close monitoring and appropriate antimicrobial prophylaxis. Genberg and colleagues reported similar results in a group of patients that received rituximab for ABOi transplantation. ${ }^{41}$ There were no significant differences in infectious complications after three years of follow-up compared to patients that underwent $\mathrm{ABO}$ compatible transplants during the same time period.

In summary, serious infectious complications have been noted in the literature after rituximab administration. However, with appropriate surveillance, the risk can be minimized. Consideration should be given to monitoring JCV to prevent PML, especially in those patients who receive agents that alter T-cell function in addition to rituximab. The neurological status of patients who receive rituximab should also be monitored. One should consider an infectious etiology for hematologic disturbances acquired after rituximab therapy. Avoidance of over immunosuppression may reduce the risk of infectious complications. Monitoring T-cell function with specific assays, such as Cylex ${ }^{\circledR}$, is helpful for identifying individuals who are over immunosuppressed and will allow for proactive adjustment of the immunosuppression regimen.

\section{Risks and side effects}

The side effects associated with rituximab are mostly related to infusion reactions. Adverse reactions at the time of infusion include fever, chills, tachycardia, arthralgias, and hypotension. ${ }^{7,65}$ These reactions occur more frequently with the first dose. A cytokine release syndrome is described in patients being treated for lymphoma, especially if there is a large tumor burden. Prophylaxis is recommended by premedicating with antipyretics, steroids, and antihistamines. However, infusion reactions may still occur despite these measures.

Long-term risks of rituximab are related to infectious complications and hematologic abnormalities. Late onset neutropenia is well documented in the literature. ${ }^{14,40,115}$ It may be associated with or without leukopenia, and infections have not been reported. It tends to resolve without intervention. Anemia and thrombocytopenia can also occur. Finally, agammaglobulinemia is a very rare complication of rituximab therapy, but should be monitored ${ }^{116}$ (Table 3).

\section{Dosing}

The optimal dosing of rituximab for use in renal transplantation is unknown. Dosing based on body surface area (BSA) and fixed dosing have both been used for desensitization, ABOi preconditioning and treatment of AMR. The dose used for B-cell lymphomas is typically $375 \mathrm{mg} / \mathrm{m}^{2}$ BSA given weekly for four weeks. The high cumulative dose is likely needed because of the tumor burden. However, a single dose of rituximab $\left(375 \mathrm{mg} / \mathrm{m}^{2}\right)$ in renal transplant recipients effectively depletes B-cells from the peripheral blood and significantly decreases their numbers in lymphoid organs and allografts. ${ }^{23,50}$ Doses as low as $20 \mathrm{mg} / \mathrm{m}^{2}$ can completely eliminate B cells from the circulation in renal transplant recipients. ${ }^{117}$ In addition, a dose as low as $10 \mathrm{mg} / \mathrm{m}^{2}$ was able to reduce the number of B-cells in the spleen. ${ }^{117}$

Dosing based on BSA may not be necessary. No improvement in the predictability of the area under the curve (AUC) was seen with rituximab dose based on BSA

Table 3 Immediate and long-term side effects of rituximab administration

\begin{tabular}{ll}
\hline Infusion-related adverse reactions & Long-term side effects \\
\hline Fever & Leukopenia \\
Chills & Neutropenia \\
Tachycardia & Agammaglobulinemia \\
Hypotension & \\
Arthralgias & \\
\hline
\end{tabular}


compared to a fixed dose of rituximab in rheumatoid arthritis patients. ${ }^{118}$ Fixed doses of rituximab are now used to treat renal transplant recipients in a variety of situations. A single low-dose of rituximab, $500 \mathrm{mg}$, was sufficient to successfully treat seven patients with refractory AMR. ${ }^{53} \mathrm{~A}$ low, fixed dose of rituximab has also been used successfully in a preconditioning regimen for ABOi transplantation. ${ }^{40}$ At Cedars-Sinai Medical Center, we use a fixed dose of rituximab, $1 \mathrm{~g}$, as part of our ABOi preconditioning regimen and desensitization protocol. $^{7,45}$

Several dosing regimens are reported for use in transplant recipients. A fixed-dose regimen seems appropriate given the inability of normalization to BSA to predict the AUC. A fixed dose would also facilitate administration and help reduce drug-dosing errors. The dose used may depend on the underlying condition being treated in this population. Patients with PTLD may require the standard weekly dosing compared to those with AMR who may be treated with a fixed, single dose. Prospective, randomized trials will need to be done to examine the efficacy of different dosing regimens on the various treatment indications.

\section{On the horizon}

There are a number of new agents now under development that could have applications for prevention and treatment of antibody-mediated conditions in transplantation. The most notable at this time is the proteosome inhibitor bortezomib. Bortezomib is currently approved for the treatment of multiple myeloma, however its plasma cell-depleting properties make it an attractive agent for use in desensitization protocols and treatment of AMR. This agent has the ability to eliminate DSA and treat both CMR and AMR. ${ }^{119,120}$ Clinical trials are needed to confirm these findings. Emerging biologic agents that are similar to rituximab include epratuzumab which binds to CD22 present on mature B-cells and therefore may deplete B-cells bound for memory or antibody production without depleting the whole population of cells. Two agents, belimumab and atacicept, inhibit the B lymphocyte stimulator/ B-cell activating factor (BLyS/BAFF) pathway which plays a role in the development of B-cells and plasma cells. These agents are in development for the treatment of multiple myeloma, systemic lupus erythematosus, and rheumatoid arthritis. The anti-complement C5 inhibitor eculizumab shows promise for prevention and treatment of AMR. ${ }^{46,121}$ It is currently approved for the chronic treatment of paroxysmal nocturnal hemoglobinuria. It prevents cellular necrosis by inhibiting the membrane attack complex from forming. This may allow a window of opportunity for antibody altering therapies to take effect. Finally, several humanized and human anti-CD20 biologics are under investigation for treatment of hematologic malignancies and autoimmune disorders. These include ocrelizumab, veltuzumab, and ofatumumab. Potential advantages of these agents include shorter infusion time, differing CDC and ADCC, less infusion reactions, and subcutaneous administration. However, approval of these drugs for use in transplantation will likely not be obtained and their use in kidney transplantation has not been reported.

\section{Conclusion}

Rituximab now plays a prominent role in the field of renal transplantation. Its uses are varied and range from facilitating desensitization and ABOi transplantation to the treatment of AMR, PTLD, and recurrent diseases in the renal allograft. Its effect on these processes is evident through its depletion of B-cells both in the peripheral blood, lymph tissues, and renal allograft. The most evidence exists for its use in PTLD. It has proven efficacy for desensitization, ABOi transplantation, and treatment of AMR, but prospective randomized trials are lacking. Only case reports exist in regards to its use in de novo and recurrent diseases in the renal allograft. The optimal dosing has not been determined and may depend on the specific indication it is being used for. Infectious complications are noted throughout the literature and surveillance for viral disease, especially $\mathrm{CMV}$, is recommended in renal transplant recipients. The occurrence of PML is rare and not reported in the renal transplant population, but patients should be monitored closely for signs and symptoms of this disease. New biologic agents are under investigation for the treatment of antibody-mediated conditions, however their use in kidney transplantation, although promising, is still experimental.

\section{Disclosures}

The authors report no conflicts of interest in this work.

\section{References}

1. Evans RW, Manninen DL, Garrison LP Jr, et al. The quality of life of patients with end-stage renal disease. $N$ Engl J Med. 1985;312(9):553-559.

2. Russell JD, Beecroft ML, Ludwin D, Churchill DN. The quality of life in renal transplantation - a prospective study. Transplantation. 1992;54(4):656-660

3. Port FK, Wolfe RA, Mauger EA, Berling DP, Jiang K. Comparison of survival probabilities for dialysis patients vs cadaveric renal transplant recipients. JAMA. 1993;270(11):1339-1343.

4. Organ Procurement and Transplantation Network. Available from: http://optn.transplant.hrsa.gov/. Accessed April 13, 2009.

5. Sonnenday CJ, Warren DS, Cooper M, et al. Plasmapheresis, CMV hyperimmune globulin, and anti-CD20 allow ABO-incompatible renal transplantation without splenectomy. Am J Transplant. 2004;4(8): $1315-1322$. 
6. Jordan SC, Tyan D, Stablein D, et al. Evaluation of intravenous immunoglobulin as an agent to lower allosensitization and improve transplantation in highly sensitized adult patients with end-stage renal disease: report of the NIH IG02 trial. J Am Soc Nephrol. 2004;15(12):3256-3262.

7. Vo AA, Lukovsky M, Toyoda M, et al. Rituximab and intravenous immune globulin for desensitization during renal transplantation. $N E n g l$ J Med. 2008;359(3):242-251.

8. Singh N, Pirsch J, Samaniego M. Antibody-mediated rejection: treatment alternatives and outcomes. Transplant Rev (Orlando) 2009;23(1):34-46

9. Pescovitz MD. B cells: a rational target in alloantibody-mediated solid organ transplantation rejection. Clin Transplant. 2006;20(1):48-54.

10. Glotz D, Antoine C, Julia P, et al. Desensitization and subsequent kidney transplantation of patients using intravenous immunoglobulins (IVIg) Am J Transplant. 2002;2(8):758-760.

11. Glotz D, Antoine C, Julia P, et al. Intravenous immunoglobulins and transplantation for patients with anti-HLA antibodies. Transpl Int. 2004;17(1):1-8.

12. Zarkhin V, Li L, Kambham N, Sigdel T, Salvatierra O, Sarwal MM A randomized, prospective trial of rituximab for acute rejection in pediatric renal transplantation. Am J Transplant. 2008;8(12):2607-2617.

13. Kaposztas Z, Podder H, Mauiyyedi S, et al. Impact of rituximab therapy for treatment of acute humoral rejection. Clin Transplant 2009;23(1):63-73.

14. Faguer S, Kamar N, Guilbeaud-Frugier C, et al. Rituximab therapy for acute humoral rejection after kidney transplantation. Transplantation. 2007;83(9):1277-1280.

15. Jordan SC, Pescovitz MD. Presensitization: the problem and its management. Clin J Am Soc Nephrol. 2006;1(3):421-432.

16. Reff ME, Carner K, Chambers KS, et al. Depletion of B cells in vivo by a chimeric mouse human monoclonal antibody to CD20. Blood. 1994;83(2):435-445

17. Edwards JC, Szczepanski L, Szechinski J, et al. Efficacy of B-celltargeted therapy with rituximab in patients with rheumatoid arthritis. N Engl J Med. 2004;350(25):2572-2581.

18. Salama AD, Pusey CD. Drug insight: rituximab in renal disease and transplantation. Nat Clin Pract Nephrol. 2006;2(4):221-230.

19. Edwards JC, Cambridge G. B-cell targeting in rheumatoid arthritis and other autoimmune diseases. Nat Rev Immunol. 2006;6(5):394-403.

20. Liossis SN, Sfikakis PP. Rituximab-induced B cell depletion in autoimmune diseases: potential effects on T cells. Clin Immunol. 2008;127(3):280-285.

21. Stasi R, Cooper N, Del Poeta G, et al. Analysis of regulatory T-cell changes in patients with idiopathic thrombocytopenic purpura receiving $\mathrm{B}$ celldepleting therapy with rituximab. Blood. 2008;112(4):1147-1150.

22. Markasz L, Vanherberghen B, Flaberg E, et al. NK cell-mediated lysis is essential to kill Epstein-Barr virus transformed lymphoblastoid B cells when using rituximab. Biomed Pharmacother. 2009;63(6):413-420.

23. Genberg H, Hansson A, Wernerson A, Wennberg L, Tyden G. Pharmacodynamics of rituximab in kidney transplantation. Transplantation. 2007;84(12 Supp1):S33-S36.

24. Ramos EJ, Pollinger HS, Stegall MD, Gloor JM, Dogan A, Grande JP. The effect of desensitization protocols on human splenic B-cell populations in vivo. Am J Transplant. 2007;7(2):402-407.

25. Anolik JH, Barnard J, Owen T, et al. Delayed memory B cell recovery in peripheral blood and lymphoid tissue in systemic lupus erythematosus after B cell depletion therapy. Arthritis Rheum. 2007;56(9):3044-3056.

26. Levesque MC, St Clair EW. B cell-directed therapies for autoimmune disease and correlates of disease response and relapse. J Allergy Clin Immunol. 2008;121(1):13-21, quiz 22-13.

27. Jordan S. IVIG vs plasmapheresis for desensitization: which is better? Am J Transplant. 2006;6(7):1510-1511.

28. Matignon M, Tagnaouti M, Audard V, Dahan K, Lang P, Grimbert P. Failure of anti-CD20 monoclonal antibody therapy to prevent antibodymediated rejection in three crossmatch-positive renal transplant recipients. Transplant Proc. 2007;39(8):2565-2567.
29. Amante AJ, Ejercito R. Management of highly sensitized patients: capitol medical center experience. Transplant Proc. 2008;40(7):2274-2280.

30. Yoon HE, Hyoung BJ, Hwang HS, et al. Successful renal transplantation with desensitization in highly sensitized patients: a single center experience. J Korean Med Sci. 2009;24(Suppl):S148-S155.

31. Kim SM, Lee C, Lee JP, et al. Kidney transplantation in sensitized recipients; a single center experience. J Korean Med Sci. 2009; 24(Suppl):S143-S147.

32. Munoz AS, Rioveros AA, Cabanayan-Casasola CB, Danguilan RA, Ona ET. Rituximab in highly sensitized kidney transplant recipients. Transplant Proc. 2008;40(7):2218-2221.

33. Vo A. American Transplant Congress 2009 Abstract \#3112009.

34. Bearden CM, Agarwal A, Book BK, et al. Pronase treatment facilitates alloantibody flow cytometric and cytotoxic crossmatching in the presence of rituximab. Hum Immunol. 2004;65(8):803-809.

35. Alexandre GP, Squifflet JP, De Bruyere M, et al. Present experiences in a series of $26 \mathrm{ABO}$-incompatible living donor renal allografts. Transplant Proc. 1987;19(6):4538-4542.

36. Sawada T, Fuchinoue S, Teraoka S. Successful A1-to-OABO-incompatible kidney transplantation after a preconditioning regimen consisting of anti-CD20 monoclonal antibody infusions, splenectomy, and doublefiltration plasmapheresis. Transplantation. 2002;74(9):1207-1210.

37. Tyden G, Kumlien G, Fehrman I. Successful ABO-incompatible kidney transplantations without splenectomy using antigen-specific immunoadsorption and rituximab. Transplantation. 2003;76(4):730-731.

38. Tyden G, Kumlien G, Genberg H, Sandberg J, Lundgren T, Fehrman I. ABO-incompatible kidney transplantation and rituximab. Transplant Proc. 2005;37(8):3286-3287.

39. Usui M, Isaji S, Mizuno S, Sakurai H, Uemoto S. Experiences and problems pre-operative anti-CD20 monoclonal antibody infusion therapy with splenectomy and plasma exchange for ABO-incompatible living-donor liver transplantation. Clin Transplant. 2007;21(1):24-31.

40. Tanabe K. Japanese experience of ABO-incompatible living kidney transplantation. Transplantation. 2007;84(12 Suppl):S4-S7.

41. Genberg H, Kumlien G, Wennberg L, Berg U, Tyden G. ABO-incompatible kidney transplantation using antigen-specific immunoadsorption and rituximab: a 3-year follow-up. Transplantation. 2008;85(12): 1745-1754.

42. Montgomery RA, Locke JE, King KE, et al. ABO incompatible renal transplantation: a paradigm ready for broad implementation. Transplantation. 2009;87(8):1246-1255.

43. Villicana R. [abstract]. Am J Transplant. 2009 May;9(S2):560, \#1325.

44. Wu GD, He Y, Chai NN, et al. Anti-CD20 antibody suppresses anti-HLA antibody formation in a HLA-A2 transgenic mouse model of sensitization. Transpl Immunol. 2008;19(3-4):178-186.

45. Jordan SC, Peng A, Vo AA. Therapeutic strategies in management of the highly HLA-sensitized and ABO-incompatible transplant recipients. Contrib Nephrol. 2009;162:13-26.

46. Stegall MD. Prevention of acute hemoral rejection with $\mathrm{C} 5$ inhibition [abstract]. Am J Transplant. 2009;9(s2):1, \#178.

47. Locke J. [abstract]. Am J Transplant. 2009;9(s2):1, \#176.

48. Sarwal M, Chua MS, Kambham N, et al. Molecular heterogeneity in acute renal allograft rejection identified by DNA microarray profiling. N Engl J Med. 2003;349(2):125-138.

49. Hippen BE, DeMattos A, Cook WJ, Kew CE 2nd, Gaston RS. Association of $\mathrm{CD} 20^{+}$infiltrates with poorer clinical outcomes in acute cellular rejection of renal allografts. Am J Transplant. 2005;5(9):2248-2252.

50. Steinmetz OM, Lange-Husken F, Turner JE, et al. Rituximab removes intrarenal B cell clusters in patients with renal vascular allograft rejection. Transplantation. 2007;84(7):842-850.

51. Becker YT, Becker BN, Pirsch JD, Sollinger HW. Rituximab as treatment for refractory kidney transplant rejection. Am J Transplant. 2004;4(6):996-1001.

52. Celik A, Saglam F, Cavdar C, et al. Successful therapy with rituximab of refractory acute humoral renal transplant rejection: a case report. Transplant Proc. 2008;40(1):302-304. 
53. Mulley WR, Hudson FJ, Tait BD, et al. A single low-fixed dose of rituximab to salvage renal transplants from refractory antibodymediated rejection. Transplantation. 2009;87(2):286-289.

54. Jordan SC, Vo AA, Tyan D, Nast CC, Toyoda M. Current approaches to treatment of antibody-mediated rejection. Pediatr Transplant. 2005;9(3):408-415.

55. Moscoso-Solorzano GT, Baltar JM, Seco M, Lopez-Larrea C, Mastroianni-Kirsztajn G, Ortega F. Single dose of rituximab plus plasmapheresis in an HIV patient with acute humoral kidney transplant rejection: a case report. Transplant Proc. 2007;39(10):3460-3462.

56. Wade E, Goral S, Kearns J, et al. Experience with antibody-mediated rejection in kidney allograft recipients. Clin Transpl. 2006:439-446.

57. Yang YW, Lin WC, Wu MS, Lee PH, Tsai MK. Early diagnosis and successful treatment of acute antibody-mediated rejection of a renal transplant. Exp Clin Transplant. 2008;6(3):211-214.

58. Solez K, Colvin RB, Racusen LC, et al. Banff '05 Meeting Report: differential diagnosis of chronic allograft injury and elimination of chronic allograft nephropathy ('CAN'). Am J Transplant. 2007;7(3): $518-526$.

59. Worthington JE, McEwen A, McWilliam LJ, Picton ML, Martin S. Association between $\mathrm{C} 4 \mathrm{~d}$ staining in renal transplant biopsies, production of donor-specific HLA antibodies, and graft outcome. Transplantation. 2007;83(4):398-403.

60. Billing H, Rieger S, Ovens J, et al. Successful treatment of chronic antibody-mediated rejection with IVIG and rituximab in pediatric renal transplant recipients. Transplantation. 2008;86(9):1214-1221.

61. Svoboda J, Kotloff R, Tsai DE. Management of patients with post-transplant lymphoproliferative disorder: the role of rituximab. Transpl Int. 2006;19(4):259-269.

62. Lee JJ, Lam MS, Rosenberg A. Role of chemotherapy and rituximab for treatment of posttransplant lymphoproliferative disorder in solid organ transplantation. Ann Pharmacother. 2007;41(10):1648-1659.

63. Swinnen LJ, LeBlanc M, Grogan TM, et al. Prospective study of sequential reduction in immunosuppression, interferon alpha-2B, and chemotherapy for posttransplantation lymphoproliferative disorder. Transplantation. 2008;86(2):215-222.

64. Lim WH, Russ GR, Coates PT. Review of Epstein-Barr virus and posttransplant lymphoproliferative disorder post-solid organ transplantation. Nephrology (Carlton). 2006;11(4):355-366.

65. Becker YT, Samaniego-Picota M, Sollinger HW. The emerging role of rituximab in organ transplantation. Transpl Int. 2006;19(8):621-628.

66. Kordelas L, Trenschel R, Koldehoff M, Elmaagacli A, Beelen DW. Successful treatment of EBV PTLD with CNS lymphomas with the monoclonal anti-CD20 antibody rituximab. Onkologie. 2008;31(12): 691-693.

67. Choquet S, Leblond V, Herbrecht R, et al. Efficacy and safety of rituximab in B-cell post-transplantation lymphoproliferative disorders: results of a prospective multicenter phase 2 study. Blood. 2006;107(8):3053-3057.

68. Oertel SH, Verschuuren E, Reinke P, et al. Effect of anti-CD 20 antibody rituximab in patients with post-transplant lymphoproliferative disorder (PTLD). Am J Transplant. 2005;5(12):2901-2906.

69. Blaes AH, Peterson BA, Bartlett N, Dunn DL, Morrison VA. Rituximab therapy is effective for posttransplant lymphoproliferative disorders after solid organ transplantation: results of a phase II trial. Cancer. 2005;104(8):1661-1667.

70. Trappe R, Riess H, Babel N, et al. Salvage chemotherapy for refractory and relapsed posttransplant lymphoproliferative disorders (PTLD) after treatment with single-agent rituximab. Transplantation. 2007;83(7):912-918.

71. Orjuela M, Gross TG, Cheung YK, Alobeid B, Morris E, Cairo MS. A pilot study of chemoimmunotherapy (cyclophosphamide, prednisone, and rituximab) in patients with post-transplant lymphoproliferative disorder following solid organ transplantation. Clin Cancer Res. 2003; 9(10 Pt 2):3945S-3952S

72. Elstrom RL, Andreadis C, Aqui NA, et al. Treatment of PTLD with rituximab or chemotherapy. Am J Transplant. 2006;6(3):569-576.
73. Meerbach A, Wutzler P, Hafer R, Zintl F, Gruhn B. Monitoring of Epstein-Barr virus load after hematopoietic stem cell transplantation for early intervention in post-transplant lymphoproliferative disease. J Med Virol. 2008;80(3):441-454.

74. Comoli P, Basso S, Zecca M, et al. Preemptive therapy of EBV-related lymphoproliferative disease after pediatric haploidentical stem cell transplantation. Am J Transplant. 2007;7(6):1648-1655.

75. Yabu JM, Ho B, Scandling JD, Vincenti F. Rituximab failed to improve nephrotic syndrome in renal transplant patients with recurrent focal segmental glomerulosclerosis. Am J Transplant. 2008;8(1):222-227.

76. Meyer TN, Thaiss F, Stahl RA. Immunoadsorbtion and rituximab therapy in a second living-related kidney transplant patient with recurrent focal segmental glomerulosclerosis. Transpl Int. 2007;20(12): 1066-1071.

77. Westphal S, Hansson S, Mjornstedt L, Molne J, Swerkersson S, Friman S. Early recurrence of nephrotic syndrome (immunoglobulin m nephropathy) after renal transplantation successfully treated with combinations of plasma exchanges, immunoglobulin, and rituximab. Transplant Proc. 2006;38(8):2659-2660.

78. Hristea D, Hadaya K, Marangon N, et al. Successful treatment of recurrent focal segmental glomerulosclerosis after kidney transplantation by plasmapheresis and rituximab. Transpl Int. 2007;20(1): 102-105.

79. Bayrakci US, Baskin E, Sakalli H, Karakayali H, Haberal M. Rituximab for post-transplant recurrences of FSGS. Pediatr Transplant. 2009;13(2):240-243.

80. Pescovitz MD, Book BK, Sidner RA. Resolution of recurrent focal segmental glomerulosclerosis proteinuria after rituximab treatment. N Engl J Med. 2006;354(18):1961-1963.

81. Gossmann J, Scheuermann EH, Porubsky S, Kachel HG, Geiger H, Hauser IA. Abrogation of nephrotic proteinuria by rituximab treatment in a renal transplant patient with relapsed focal segmental glomerulosclerosis. Transpl Int. 2007;20(6):558-562.

82. Remuzzi G, Chiurchiu C, Abbate M, Brusegan V, Bontempelli M, Ruggenenti P. Rituximab for idiopathic membranous nephropathy. Lancet. 2002;360(9337):923-924.

83. Gallon L, Chhabra D. Anti-CD20 monoclonal antibody (rituximab) for the treatment of recurrent idiopathic membranous nephropathy in a renal transplant patient. Am J Transplant. 2006;6(12):3017-3021.

84. Weclawiak H, Ribes D, Guilbeau-Frugier C, et al. Relapse of membranous glomerulopathy after kidney transplantation: sustained remittance induced by rituximab. Clin Nephrol. 2008;69(5):373-376.

85. Weclawiak H, Ribes D, Modesto A, Kamar N, Durand D, Rostaing L. [Efficiency of rituximab treatment for recurrence of membranous glomerulopathy after renal transplantation]. Nephrol Ther. 2007; $3(2): 65-68$.

86. Sirimongkolrat T, Premasathian N, Vongwiwatana A, Limsrichamrern S, Cheunsuchon B, Vasuvattakul S. Anti-CD20 monoclonal antibody (rituximab) for the treatment of membranous nephropathy after living-unrelated kidney transplantation: a case report. Transplant Proc. 2008;40(7):2440-2441.

87. Geetha D, Seo P. Renal transplantation in the ANCA-associated vasculitides. Am J Transplant. 2007;7(12):2657-2662.

88. Geetha D, Seo P, Specks U, Fervenza FC. Successful induction of remission with rituximab for relapse of ANCA-associated vasculitis post-kidney transplant: report of two cases. Am J Transplant. 2007;7(12):2821-2825.

89. Gera M, Griffin MD, Specks U, Leung N, Stegall MD, Fervenza FC. Recurrence of ANCA-associated vasculitis following renal transplantation in the modern era of immunosupression. Kidney Int. 2007;71(12): 1296-1301.

90. Roccatello D, Baldovino S, Alpa M, et al. Effects of anti-CD20 monoclonal antibody as a rescue treatment for ANCA-associated idiopathic systemic vasculitis with or without overt renal involvement. Clin Exp Rheumatol. 2008;26(3 Suppl 49):S67-S71.

91. Hinze $\mathrm{CH}$, Colbert RA. B-cell depletion in Wegener's granulomatosis. Clin Rev Allergy Immunol. 2008;34(3):372-379. 
92. Hermle T, Goestemeyer AK, Sweny P, Burns A. Successful therapeutic use of rituximab in refractory Wegener's granulomatosis after renal transplantation. Clin Nephrol. 2007;68(5):322-326.

93. Basse G, Ribes D, Kamar N, et al. Rituximab therapy for de novo mixed cryoglobulinemia in renal transplant patients. Transplantation. 2005;80(11):1560-1564.

94. Basse G, Ribes D, Kamar N, et al. Rituximab therapy for mixed cryoglobulinemia in seven renal transplant patients. Transplant Proc. 2006;38(7):2308-2310.

95. Bestard O, Cruzado JM, Ercilla G, et al. Rituximab induces regression of hepatitis $\mathrm{C}$ virus-related membranoproliferative glomerulonephritis in a renal allograft. Nephrol Dial Transplant. 2006;21(8):2320-2324.

96. Perico N, Cattaneo D, Bikbov B, Remuzzi G. Hepatitis C infection and chronic renal diseases. Clin J Am Soc Nephrol. 2009;4(1):207-220.

97. Roccatello D, Baldovino S, Rossi D, et al. Long-term effects of antiCD20 monoclonal antibody treatment of cryoglobulinaemic glomerulonephritis. Nephrol Dial Transplant. 2004;19(12):3054-3061.

98. Zaja F, De Vita S, Mazzaro C, et al. Efficacy and safety of rituximab in type II mixed cryoglobulinemia. Blood. 2003;101(10):3827-3834

99. Ponticelli C, Banfi G. Thrombotic microangiopathy after kidney transplantation. Transpl Int. 2006;19(10):789-794.

100. Ponticelli C. De novo thrombotic microangiopathy. An underrated com plication of renal transplantation. Clin Nephrol. 2007;67(6):335-340.

101. Yassa SK, Blessios G, Marinides G, Venuto RC. Anti-CD20 monoclonal antibody (Rituximab) for life-threatening hemolytic-uremic syndrome. Clin Transplant. 2005;19(3):423-426.

102. Sadler JE. von Willebrand factor, ADAMTS13, and thrombotic thrombocytopenic purpura. Blood. 2008;112(1):11-18.

103. Dias PJ, Gopal S. Refractory thrombotic thrombocytopenic purpura following influenza vaccination. Anaesthesia. 2009;64(4):444-446.

104. Fakhouri F, Vernant JP, Veyradier A, et al. Efficiency of curative and prophylactic treatment with rituximab in ADAMTS13-deficient thrombotic thrombocytopenic purpura: a study of 11 cases. Blood. 2005;106(6):1932-1937.

105. Rufer A, Brodmann D, Gregor M, Kremer Hovinga JA, Lammle B, Wuillemin WA. Rituximab for acute plasma-refractory thrombotic thrombocytopenic purpura. A case report and concise review of the literature. Swiss Med Wkly. 2007;137(37-38):518-524.

106. Grim SA, Pham T, Thielke J, et al. Infectious complications associated with the use of rituximab for $\mathrm{ABO}$-incompatible and positive cross-match renal transplant recipients. Clin Transplant. 2007;21(5):628-632.

107. Tanriover B, Wright SE, Foster SV, et al. High-dose intravenous immunoglobulin and rituximab treatment for antibody-mediated rejection after kidney transplantation: a cost analysis. Transplant Proc. 2008;40(10):3393-3396.
108. Aksoy S, Harputluoglu H, Kilickap S, et al. Rituximab-related viral infections in lymphoma patients. Leuk Lymphoma. 2007;48(7): 1307-1312.

109. Carson KR, Bennett CL. Rituximab and progressive multi-focal leukoencephalopathy: the jury is deliberating. Leuk Lymphoma. 2009;50(3):323-324.

110. Carson KR, Evens AM, Richey EA, et al. Progressive multifocal leukoencephalopathy following rituximab therapy in HIV negative patients: a report of 57 cases from the Research on Adverse Drug Event and Reports (RADAR) project. Blood. 2009;113(20):4834-4840.

111. Kamar N, Mengelle C, Rostaing L. Incidence of JC-virus replication after rituximab therapy in solid-organ transplant patients. $\mathrm{Am} \mathrm{J}$ Transplant. 2009;9(1):244-245.

112. Klepfish A, Rachmilevitch E, Schattner A. Parvovirus B19 reactivation presenting as neutropenia after rituximab treatment. Eur J Intern Med. 2006;17(7):505-507.

113. Sharma VR, Fleming DR, Slone SP. Pure red cell aplasia due to parvovirus B19 in a patient treated with rituximab. Blood. 2000;96(3):1184-1186.

114. Vo AA, Wechsler EA, Wang J, et al. Analysis of subcutaneous (SQ) alemtuzumab induction therapy in highly sensitized patients desensitized with IVIG and rituximab. Am J Transplant. 2008;8(1):144-149.

115. Mitsuhata N, Fujita R, Ito S, Mannami M, Keimei K. Delayed-onset neutropenia in a patient receiving rituximab as treatment for refractory kidney transplantation. Transplantation. 2005;80(9):1355.

116. Guerin V, Yakouben K, Lescoeur B, et al. Prolonged agammaglobulinemia despite unaltered B-cell lymphopoiesis after peritransplantrituximab administration in a child. Transplantation. 2008;86(9): $1322-1323$.

117. Toki D, Ishida H, Horita S, Setoguchi K, Yamaguchi Y, Tanabe K. Impact of low-dose rituximab on splenic B cells in ABO-incompatible renal transplant recipients. Transpl Int. 2009;22(4):447-454.

118. Ng CM, Bruno R, Combs D, Davies B. Population pharmacokinetics of rituximab (anti-CD20 monoclonal antibody) in rheumatoid arthritis patients during a phase II clinical trial. J Clin Pharmacol. 2005;45(7):792-801.

119. Trivedi HL, Terasaki PI, Feroz A, et al. Abrogation of anti-HLA antibodies via proteasome inhibition. Transplantation. 2009;87(10): 1555-1561.

120. Everly MJ, Everly JJ, Susskind B, et al. Bortezomib provides effective therapy for antibody- and cell-mediated acute rejection. Transplantation. 2008;86(12):1754-1761.

121. Locke JE, Magro CM, Singer AL, et al. The use of antibody to complement protein C5 for salvage treatment of severe antibody-mediated rejection. Am J Transplant. 2009;9(1):231-235.
Transplant Research and Risk Management

\section{Publish your work in this journal}

Transplant Research and Risk Management is an international, peerreviewed open access journal focusing on all aspects of transplantation and risk management to achieve optimal outcomes in the recipient improving survival and quality of life. The journal welcomes submitted papers covering original research, basic science, clinical studies,

\section{Dovepress}

reviews \& evaluations, guidelines, expert opinion and commentary, case reports and extended reports. The manuscript management system is completely online and includes a very quick and fair peer-review system, which is all easy to use. Visit http://www.dovepress.com/ testimonials.php to read real quotes from published authors. 